\title{
Tundra Fire Regimes in the Noatak River Watershed, Alaska: 1956-83
}

\author{
CHARLES H. RACINE,' JOHN G. DENNIS, ${ }^{2}$ and WILLIAM A. PATTERSON $1 \mathrm{II}^{3}$
}

\begin{abstract}
The location, cause, frequency, size, rotation times, and seasonal timing of tundra fires in the Noatak River watershed of northwestern Alaska were determined from Bureau of Land Management fire records for 1956-83 and satellite (LANDSAT) 1:1 000 000 scale, black and white, band 7 imagery for 1972-81. Seventy-nine fires that burned $1018 \mathrm{~km}^{2}$ were detected during the 28-year period from 1956 to 1983. Most of these occurred on the valley floor below $450 \mathrm{~m}$ in close proximity to the Noatak River or its tributaries. However, differences in mean fire size, frequency, and rotation times varied greatly among the six physiographic regions of the watershed. All fires occurred during one of two summertime periods in June and July. The implications of this seasonal timing and comparisons of the fire regimes in the Noatak with those in other ares of northern Alaska are discussed.
\end{abstract}

Key words: arctic tundra, LANDSAT imagery, Brooks Range, fire records, fire history, Alaska, Biosphere Reserves

RÉSUMÉ. L'emplacement, la cause, la fréquence, la taille, la période de rotation et la période saisonnière d'incendies dans la toundra du bassin hydrographique de la rivière Noatak au nord-ouest de l'Alaska furent déterminés à l'aide des dossiers d'incendies du Bureau de la gestion des terres pour 1956-1983 et d'images de satellites (LANDSAT) en blanc et noir et de bande 7, à l'échelle 1:1000 000, pour 1972-1981. Soixante-dix-neuf incendies qui brûlèrent $1018 \mathrm{~km}^{2}$ furent relevés durant une période de 28 années; entre 1956 et 1983 . La plupart de ces derniers se produisirent dans la plaine alluviale à une altitude inférieure à $450 \mathrm{~m}$ et près de la rivière Noatak ou de ses tributaires. Cependant, la taille moyenne des incendies, la fréquence et la période de rotation variaient de façon importante entre les six régions physiographiques du bassin hydrographique. Tous les incendies eurent lieu en juin ou en juillet durant l'une de deux périodes estivales. L'artiele discute la signification de cette périodicité saisonnière et compare les régimes d'incendies de la Noatak avec ceux d'autres régions dans le nord de l'Alaska.

Mots clés: toundra arctique, images LANDSAT, chaîne Brooks, dossiers d'incendies, histoire des incendies, Alaska, réserves de la biosphère

Traduit pour le journal par Maurice Guibord.

\section{INTRODUCTION}

The historical fire regime, defined by Heinselman (1978) as the total pattern of fires characteristic of a natural region or ecosystem, must be understood to evaluate the role of fire in an ecosystem. Recently Gabriel and Tande (1983) have regionalized fire statistical data for Alaska to make Alaskan fire history summaries more meaningful. Here we apply a similar approach to a large arctic watershed in the western Brooks Range of Alaska. Little is known about fire regimes in the vast areas of arctic tundra in northern and northwestern Alaska (Viereck and Schandelmeier, 1980). In addition, because key techniques useful in the reconstruction of fire regimes in forests (especially dendrochronology and fire-scar analysis) are inapplicable in the treeless tundra (Tande, 1979), study of tundra fire regimes depends heavily on availability of accurate fire records.

The study reported here uses both fire records and LANDSAT imagery to understand several aspects of the local tundra fire regime in the Noatak River watershed, the majority of which is a National Preserve and Biosphere Reserve, in northwestern Alaska (Fig. 1). We attempt to understand fire frequency, size, rotation times, and fire location.

The Noatak River, one of the major river systems of arctic Alaska, lies slightly north of the Arctic. Circle and drains $33670 \mathrm{~km}^{2}$ of the western Brooks Range. Tundra vegetation covers most of the watershed except for white spruce forest along the lower drainage of the Noatak and its lower tributaries (Fig. 2). In addition, small stands of balsam. poplar forest occur near the river throughout the watershed. Below an elevation of $600 \mathrm{~m}$ tussock tundra and low shrubland are dominant, with various forms of alpine tundra above this elevation. Smith (1913) defined six physiographic regions for the Noatak watershed: Coastal Lowlands, Igichuk Hills, Mission Lowlands, Second Highlands, Aniuk Lowlands, and Headwater Mountains (Fig: 1). Gabriel and Tande (1983), in their regionalization of Alaskan fire records, divided the Noatak region into three physiographic sections (Noatak Lowlands, Baird Mountains and DeLong Mountains) (defined by Warhaftig, 1965). These sections included other major watersheds to the north and south and are therefore not applicable to our Noatak watershed perspective. The area and elevational relationships for our six regions are given in Table 1.

\section{METHODS}

We used Bureau of Land Management (BLM) fire records or "fire detail sheets" to develop a list of fires occurring between 1956 and 1983 for the region between $67^{\circ}$ and $68^{\circ} 30^{\prime} \mathrm{N}$ and $153^{\circ} 30^{\prime}$ and $163^{\circ} 40^{\prime} \mathrm{W}$. For each fire included on this list we obtained the fire number, name, date of discovery, latitude and longitude coordinates, and size of the burned area (based on an estimate of the time the fire was declared out). In addition, we obtained "individual fire reports" for 1981-83 fires and for several earlier fires that could not be located on LANDSAT imagery. These fire reports often contained a sketch map of the fire location made at the time of its discovery. Using information drawn from BLM fire records, we

\footnotetext{
${ }^{1}$ Division of Environmental Studies, Johnson State College, Johnson, Vermont 05656, U.S.A:

${ }^{2}$ Biological Resources Division; National Park Service, Washington, D.C. 20240, U.S.A.

${ }^{3}$ Department of Forestry and Wildife Management, University of Massachusetts, Amherst, Massachusetts 01003, U.S.A.
} 


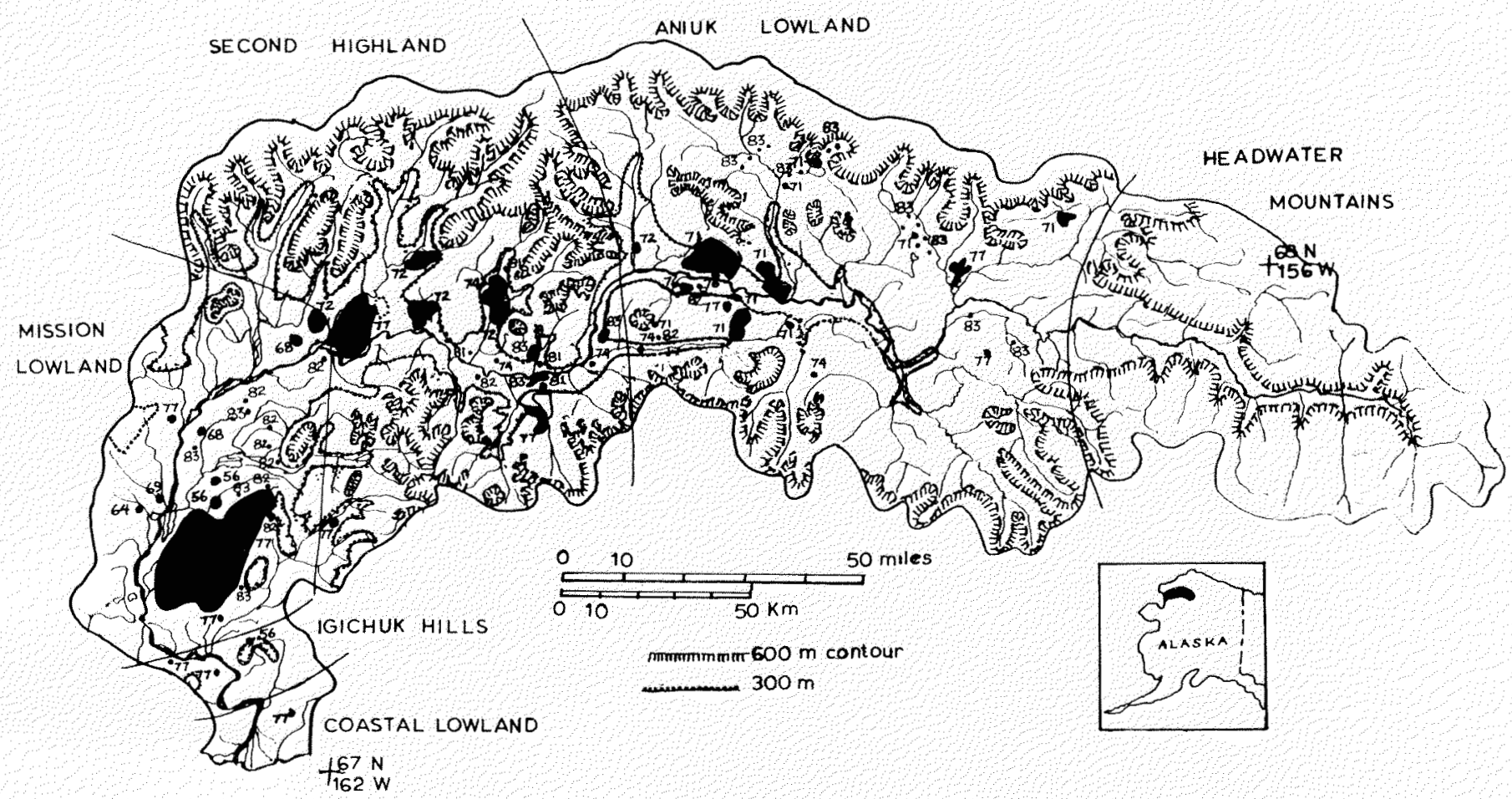

FIG. I. Map of the Noatak River watershed in the western Brooks Range, Alaska, showing six physiographic regions, $300 \mathrm{~m}$ and $600 \mathrm{~m}$ elevation contours, and the size, location, and year of fires between 1956 and 1983 based on BLM fire records and/or LANDSAT imagery. Reduced from 1:1 000000 scale World Aeronautical Charts CC-8 and CC-9.

plotted the location of all reported fires on 1:1000 000 scale world aeronautical charts (CC-8 and CC-9).

Three summer LANDSAT images in 1:1000 000 scale, black and white, band 7 format, for each year provided coverage of the entire Noatak watershed for the 1972-81 study period (Fig. 2). The exact location and aerial outline of each fire observable on the LANDSAT image (generally greater than about $13 \mathrm{ha}$ ) were mapped onto the aeronautical charts so that locational and elevational measurements and a check for agreement between BLM records and LANDSAT imagery could be obtained (Figs. 1, 2).

The locational and elevational measurements made for each fire included: a) distance upriver from the mouth of the Noatak; b) distance and direction from the main channel of the river; and c) elevational range over which the fire burned. This latter determination (c) was estimated from elevational ranges color-coded in $300 \mathrm{~m}$ intervals on the aeronautical charts.

The area burned by each fire was measured directly on the LANDSAT image. Other characteristics noted on the LANDSAT imagery were the darkness of the burned area's tone in the year of the fire and the number of years following the fire that the individual burned areas could still be distinguished.

\section{RESULTS}

\section{Assessment of the Methodology}

By using both BLM fire records from 1956 to 1983 and LANDSAT imagery from 1972 to 1981 , we found it possible to accurately locate and map tundra fires within the Noatak watershed (Figs. 1, 2). Of 36 fires listed in the BLM records as having occurred within the watershed between 1971 and 1981, 22 were located and mapped from the LANDSAT imagery. By first locating the general area burned using the BLM fire record coordinates, we found it possible to locate burned areas as small as about 15 ha. The 14 burned areas that we could not find on LANDSAT imagery were either $<15$ ha in size ( 9 areas) or occurred during 1971 prior to good LANDSAT coverage ( 5 areas). The difficulty we encountered in locating some of these 1971 fires on the LANDSAT images is unfortunate, because there were extensive tundra fires in northwest Alaska during that summer. We do not know whether the quality of the early LANDSAT imagery from 1972 and 1973 or a possible low intensity of burning by the missing 1971 fires, all of which occurred in late June, prevented us from locating them on the LANDSAT imagery. The LANDSAT imagery revealed only 2 fires that were not listed in the BLM fire records. Latitude and longitude coordinates provided in the BLM records were usually near the actual fire locations shown on the LANDSAT images. Generally, burned areas were visible on the black and white, band 7 LANDSAT imagery for up to three years following the fire but could not be seen in the fourth year.

\section{Location of Fires within the Watershed}

Virtually all of the fires reported occurred in close proximity to the valley floor of the Noatak; in several cases they were in the valleys of larger tributary streams (Figs. 1, 2). The mean distance from the Noatak River of all fires is $14 \mathrm{~km}$. About $25 \%$ of the fires burned to the banks of the Noatak River, but none jumped the river. Fires were, on the average, closest to 


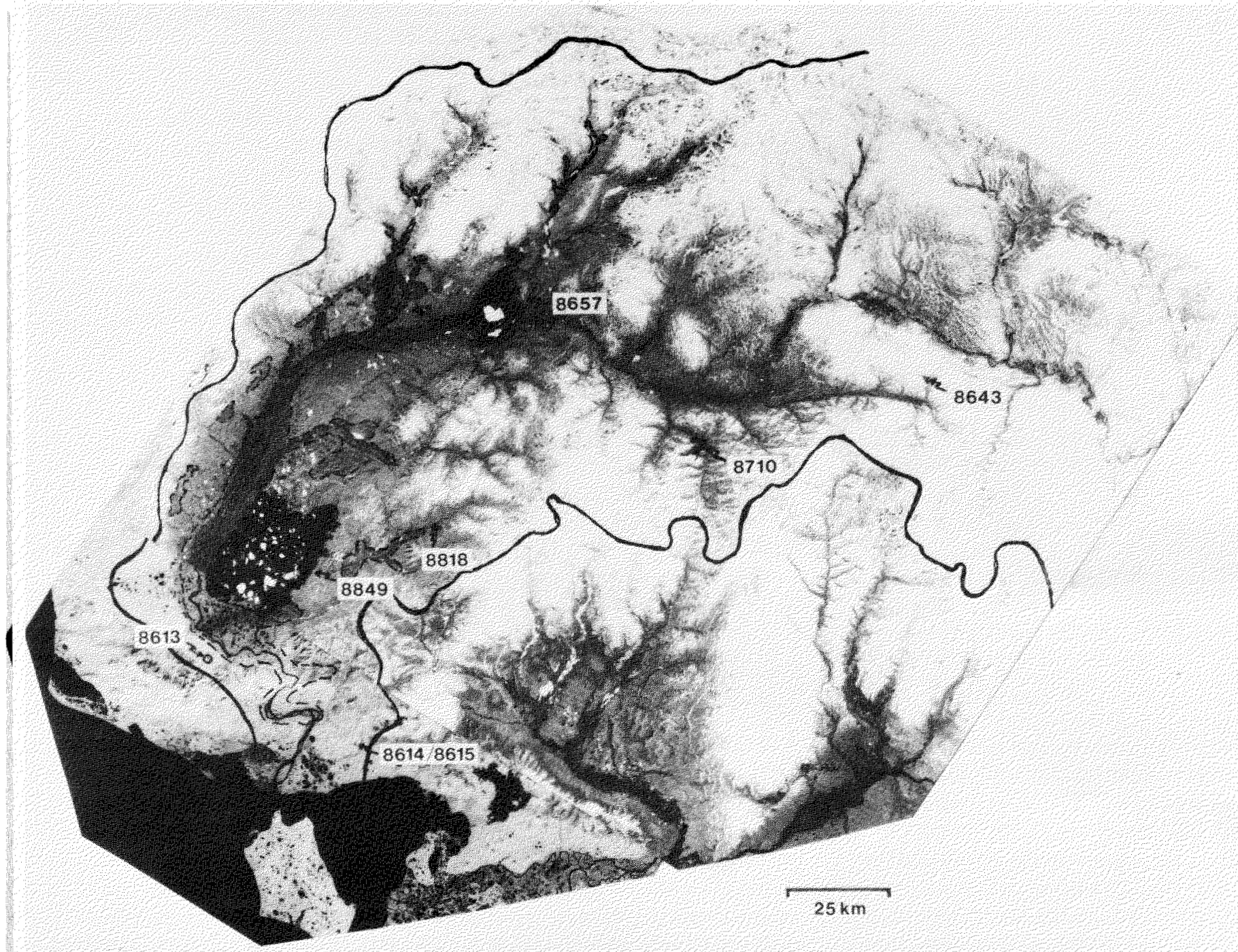

FIG. 2. LANDSAT scenes in band 7 obtained on 15 May 1978 showing $60 \%$ of the Noatak watershed and seven burned areas (marked with BLM fire identification numbers) resulting from July 1977 wildfires. The largest burned area (fire no. 8849) covered $458 \mathrm{~km}^{2}$. Spring snowmelt in this scene has reached an elevation of about $300 \mathrm{~m}$. The approximate distribution of white spruce forest in the Noatak watershed is shown by a dashed line. Parts of Kotzebue Sound, the Baldwin Peninsula, and the Kobuk River watershed are visible to the south.

TABLE 1. Size and area relationships of the six physiographic regions recognized by Smith (1913) in the Noatak River basin

\begin{tabular}{|c|c|c|c|c|c|c|}
\hline $\begin{array}{l}\text { Physiographic } \\
\text { Region }\end{array}$ & $\begin{array}{c}\text { Total } \\
\text { Area } \\
\left(\mathrm{km}^{2}\right)\end{array}$ & $\begin{array}{c}\% \text { of } \\
\text { Water- } \\
\text { shed }\end{array}$ & $\begin{array}{c}\text { Area } \\
\text { below } \\
300 \mathrm{~m} \\
\left(\mathrm{~km}^{2}\right)\end{array}$ & $\begin{array}{c}\% \text { of } \\
\text { Region } \\
\text { below } \\
300 \mathrm{~m}\end{array}$ & $\begin{array}{c}\text { Area } \\
\text { below } \\
600 \mathrm{~m} \\
\left(\mathrm{~km}^{2}\right)\end{array}$ & $\begin{array}{c}\% \text { of } \\
\text { Region } \\
\text { below } \\
600 \mathrm{~m}\end{array}$ \\
\hline \multicolumn{7}{|l|}{ Coastal } \\
\hline Lowlands & 500 & 1 & 500 & 100 & 500 & 100 \\
\hline Igichuk Hills & 610 & 2 & 486 & 80 & 610 & 100 \\
\hline \multicolumn{7}{|l|}{ Mission } \\
\hline Lowlands & 5070 & 15 & 4110 & 81 & 5030 & 99 \\
\hline \multicolumn{7}{|l|}{ Second } \\
\hline Highland & 9660 & 29 & 1980 & 20 & 6590 & 68 \\
\hline Aniuk & & & & & & \\
\hline Lowlands & 11800 & 35 & 967 & 8 & 8360 & 71 \\
\hline \multicolumn{7}{|l|}{ Headwater } \\
\hline Mountains & 6030 & 18 & 0 & $\underline{0}$ & 1130 & 19 \\
\hline \multicolumn{7}{|l|}{ Entire } \\
\hline Watershed & 33670 & 100 & 8043 & 24 & 22220 & 66 \\
\hline
\end{tabular}

Noatak River in the Second Highland area $(8.4 \mathrm{~km})$ and farthest in the Aniuk Lowlands $(16 \mathrm{~km})$. Twenty fires occurred in tributary valleys at least $15 \mathrm{~km}$ from the Noatak River. Most conspicuous of these were 1983 fires in the Aniuk Lowland, 1972 fires north of the Noatak on the Kugururok and Kaluktavik tributary rivers, and 1977 fires south of the river up several tributary valleys evident on the LANDSAT scene ( $\# 8818$ and 8810 in Fig. 2).

The upper elevational limit of fire in the Noatak watershed appears to be $450-600 \mathrm{~m}$ and may generally correspond with the upper limit of tussock and shrub-tussock tundra vegetation types. Because the base elevations of the six physiographic regions (Fig. 1) are different (Table 1), the elevation of a burn is partly determined by the region in which it occurs. Most fires in the Mission Lowlands burned at elevations between 30 $\mathrm{m}$ and $175 \mathrm{~m}$ with a mean of $152 \mathrm{~m}$, fires in the Second Highland Region occurred at elevations between $122 \mathrm{~m}$ and $457 \mathrm{~m}$ 
with a mean of $210 \mathrm{~m}$, and fires in the Aniuk Lowlands burned between elevations of $150 \mathrm{~m}$ and $760 \mathrm{~m}$ with a mean of $300 \mathrm{~m}$. Most of the fires at elevations above $300 \mathrm{~m}$ tended to be small in areal extent.

Although the Mission Lowlands region contains most of the white spruce (Picea glauca Moench (Voss)) forest outliers in the Noatak watershed (Fig. 2), there is little evidence to suggest that fires are concentrated in the forested portions of this region. Specifically, we see no evidence that tundra fires start as a result of lightning striking spruce trees with resulting fires burning into the adjacent tundra. The large $\left(458 \mathrm{~km}^{2}\right) 1977$ fire (\#8849 in Fig. 2) was, in fact, restricted to the treeless thaw lake-studded portion of the Mission Lowlands tundra, and the entire western margin of the burned area corresponds with the eastern edge of the white spruce forest. During the 1981 field season, we visited an area burned in 1977 where in some places the fire stopped at the edge of a white spruce forest and in others burned only a short distance into the stand. This correspondence could be due to different fuel types between stands or to a wetter moisture regime in white spruce forests (Quirk and Sykes, 1971). There are no open black spruce or lichen woodlands in the Noatak River watershed in which fire could be initiated.

With the exception of 1977,1982 , and 1983 fires, which occurred in at least three of the six physiographic regions (Fig. 1), our data indicate some tendency for fires of a given year to be localized in a particular physiographic region. For example, 1971 fires occurred mainly in the Aniuk Lowlands region of the upper Noatak watershed, whereas 1972, 1974, and 1981 fires occurred mainly in the middle watershed region of the Second Highlands. The heaviest concentration of reported fires occurred during 8-10 July 1983 in the Aniuk Lowlands north of the Noatak River, where 15 small fires were reported.

There are at least two confirmed instances of reburning of a recently burned area. A July 1983 fire reburned 1179 ha of an area burned six years previously (\#8657 in Fig. 2). A second July 1983 fire reburned a small portion of a 1972 burn. Both of these fires burned near the boundary between the Second Highlands and Mission Lowlands region (Fig. 1). Three small 1982 or 1983 fires may have reburned portions of the large $\left(458 \mathrm{~km}^{2}\right) 1977$ Mission Lowlands burned area.

\section{Fire Causes}

Although the proximity to the Noatak River of the fires shown in Figure 1 suggests possible causes related to human activities, all fires are listed in the BLM records as lightning caused. One 12-ha fire during August 1971, not included in our analysis, is listed as caused by smoking.

\section{Fire Frequency}

Fire statistical data and LANDSAT imagery suggest that 79 fires occurred during the past 28 years. Although this yields an average of 2.8 fires per year, fires occurred in only 12 of the 28 sample years (Fig. 3a). In years when fires did occur, the number of fires varied from 1 (in 1964 and 1969) to 25 per year (in 1983) (Fig. 3a). Hence fire statistics as calculated here
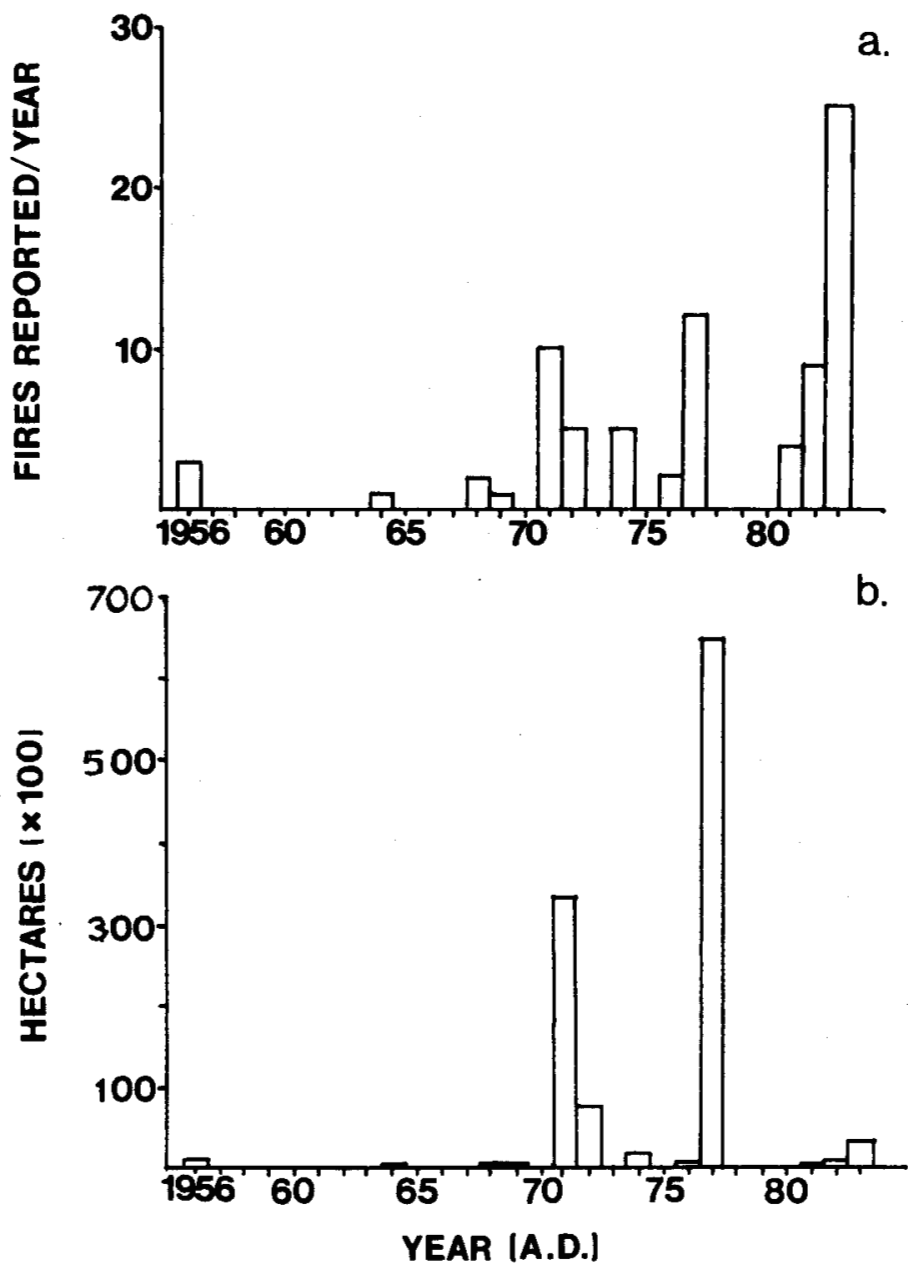

FIG. 3. (a) Number of fires reported per year for the Noatak River watershed between 1956 and 1983. (b) Area burned in the Noatak River watershed between 1956 and 1983, based on BLM records and planimetry of LANDSAT imagery.

are heavily influenced by strong year-to-year variation. The fire return interval (Gabriel and Tande, 1983) for the entire watershed is $<1 \mathrm{yr}$.

There were 0.5 fires per year during the $1956-69$ period, 3.4 fires per year during the 1970-79 period and 9.5 fires per year in 1980-83 (Table 2). The largest number of fires occurred in 1983 (25), followed by 1977 (12) and 1971 (10) (Fig. 3a). The present data base is inadequate for determining whether the higher frequency of fires during the 1970 s and 1980 s compared to the 1950s and 1960s is a result of better detection or of real weather differences. Increased visitor use and aircraft traffic in the Noatak area since its establishment as a National Preserve in 1980 have undoubtedly resulted in better fire detection. In particular, small fires of $<10$ ha that are naturally extinguished by rain would be detected more readily with increased air traffic.

The frequency of fires for the period 1956-83 varies between physiographic regions of the watershed with only 1 in the Coastal Lowlands, 3 in the Igichuk Hills, 25 in the Mission Lowlands, 18 in the Second Highlands, 32 in the Aniuk Lowlands, and none in the Headwaters Mountain (Table 2).

All of the fires prior to 1970 are listed as occurring in the 
TABLE 2. Fire frequency and predicted fire rotation times for the Noatak River watershed, Alaska

\begin{tabular}{|c|c|c|c|c|c|c|c|c|}
\hline & \multicolumn{4}{|c|}{$\begin{array}{c}\text { Number of Fires } \\
\text { Detected }\end{array}$} & \multirow{2}{*}{$\begin{array}{l}\text { Total } \\
\text { Area } \\
\text { Burned } \\
1956-83 \\
\left(\mathrm{~km}^{2}\right)\end{array}$} & \multirow{2}{*}{$\begin{array}{l}\text { Fire } \\
\text { Rotation } \\
\text { Times } \\
\text { for Area } \\
\text { below } \\
600 \mathrm{~m} \\
\text { (yr) }\end{array}$} & \multirow{2}{*}{$\begin{array}{l}\text { Fire } \\
\text { Rotation } \\
\text { Times } \\
\text { for Area } \\
\text { below } \\
450 \mathrm{~m} \\
\text { (yr) }\end{array}$} & \multirow{2}{*}{$\begin{array}{l}\text { Fire } \\
\text { Rotation } \\
\text { Times } \\
\text { for Area } \\
\text { below } \\
300 \mathrm{~m} \\
\text { (yr) }\end{array}$} \\
\hline $\begin{array}{l}\text { Physiographic } \\
\text { Region } \\
\end{array}$ & $\begin{array}{l}1956-69 \\
(14 \mathrm{yr})\end{array}$ & $\begin{array}{l}1970-79 \\
(10 \mathrm{yr})\end{array}$ & $\begin{array}{l}1980-83 \\
(4 \mathrm{yr})\end{array}$ & $\begin{array}{l}\text { Total } \\
(28 \mathrm{yr})\end{array}$ & & & & \\
\hline Coastal Lowlands & 0 & $1(1)$ & 0 & 1 & 0.3 & - & - & - \\
\hline Igichuk Hills & $1(0)$ & $2(1)$ & 0 & $3(1)$ & 0.4 & - & - & - \\
\hline Mission Lowlands & $6(3)$ & $5(5)$ & $14(8)$ & $25(16)$ & 505.5 & 279 & 252 & 228 \\
\hline Second Highland & 0 & $10(4)$ & 8 & $18(4)$ & 244.6 & 754 & 442 & 227 \\
\hline Aniuk Lowlands & 0 & $16(4)$ & $16(12)$ & $32(16)$ & 267.1 & 876 & 618 & 101 \\
\hline Headwater Mountains & 0 & 0 & 0 & 0 & 0 & - & - & - \\
\hline Whole Watershed & $7(3)$ & $34(15)$ & $38(20)$ & $79(38)$ & 1017.9 & 611 & 395 & 221 \\
\hline
\end{tabular}

( ) Values in parentheses indicate the number of fires for which suppression activities were undertaken.

Mission Lowlands and Igichuk Hills regions (Table 2). This may reflect better pre-1970 fire detection and reporting in the vicinity of Noatak Village and Kotzebue than elsewhere in the watershed, rather than a true distribution of fires. The finding that the number of fires in the Second Highland and Aniuk Lowlands regions was greater than the Mission Lowlands and Igichuk Hills regions during the period 1970-83 (Table 2) suggests a change in detection capability since 1970.

\section{Fire Sizes}

The 79 fires used in our analysis ranged in size from 0.4 ha to 45800 ha, with a mean of 1310 ha. Thirty-seven fires $(47 \%)$ were in the $1-10$ ha size class (with 20 of these occurring in 1983 alone). Thirteen fires (16\%) were 10-100 ha in size; $15(19 \%)$ were between 100 and 1000 ha in size; 11 (14\%) were between 1000 ha and 10000 ha; and 3 fires (4\%) burned more than 10000 ha each. The largest fire occurred in 1977 in the Mission Lowlands and covered $458 \mathrm{~km}^{2}$ (Figs. 1, 2 ). The many small fires $<10$ ha in size, particularly prominent in 1983 in the Aniuk Lowlands (Fig. 1), are frequently listed in the BLM individual fire reports as extinguished by rain before fire suppression activities began. It is likely that such fires were frequent but unreported in earlier years.

Although mean fire size was 1310 ha for the entire watershed, mean fire size varied with the physiographic region: 2020 ha for the Mission Lowlands, 1360 ha in the Second Highlands, and 830 ha in the Aniuk Lowlands. There were too few fires in the Coastal Lowlands and Igichuk Hills to allow us to calculate mean fire sizes.

The two major fire years, in terms of total area burned within the Noatak watershed since 1956, were 1971 and 1977 (based on BLM records), when $330 \mathrm{~km}^{2}$ and $640 \mathrm{~km}^{2}$ burned, respectively (Fig. 3b). There is close correspondence between LANDSAT-measured and BLM estimates of burn area for 1977, but we could not locate some of the 1971 BLM-reported fires on 1973 LANDSAT imagery, so the total size of area burned in 1971 is less certain than in 1977.

\section{Fire Rotation Time}

BLM fire records for the period 1956-83 and LANDSAT imagery for the period 1972-81 show 79 fires that burned an area of $1018 \mathrm{~km}^{2}$ within the $33670 \mathrm{~km}^{2}$ Noatak watershed, at an average burning rate of $34 \mathrm{~km}^{2} \cdot \mathrm{yr}^{-1}$. This yields a fire cycle or "natural fire rotation" (Heinselman, 1973) for the entire watershed of 988 years (Table 2).

However, it is clear from available data and Figure 1 that fires are confined to the lower mountain slopes and valley floor below elevations of $600 \mathrm{~m}$ and more often than not occur below elevations of $300-450 \mathrm{~m}$. The fire rotation time for the entire watershed area below $300 \mathrm{~m}$ ( $24 \%$ of watershed) is 221 years and for the area below $600 \mathrm{~m}$ ( $66 \%$ of watershed) is 611 years (Tables 1 and 2). If the land area below $450 \mathrm{~m} \mathrm{(40 \%} \mathrm{of}$ the watershed) is used as a basis for computing fire rotation times, a value of 395 years is obtained.

Because of variations in terrain, weather, and fuel factors within the Noatak watershed, there are probable differences in fire rotation times between the physiographic regions (Table 2). The shortest fire rotation time of 252 years is obtained for the Mission Lowlands below an elevation of $450 \mathrm{~m}$. The Aniuk Lowlands region below $450 \mathrm{~m}$ shows a long fire rotation time of 618 years. The predicted fire rotation time for the Second Highlands below $450 \mathrm{~m}$ is 442 years, but only 227 years for the area below $300 \mathrm{~m}$.

\section{Seasonal Timing of Fires}

All of the fires listed by BLM in the Noatak watershed are reported as having been detected during one of two summertime periods (Fig. 4): 1) 13-27 June, 29 fires; and 2) 6-31 July, 50 fires. In most years the majority of ignitions were clustered within a one- to three-day interval within only one of these two periods (e.g., in 1971, seven fires during 24-25 June and one on 12 July; in 1972, four fires during 13-15 July; and in 1974, five fires during 22-23 June). In 1977, a dry year throughout much of interior and arctic Alaska, fires were reported in the Noatak watershed on seven different days from 9 July through 31 July. The years 1981, 1982, and 1983 appear to be exceptions to the generalization that all fires in a particular year are confined to either an early or late time period. In 1983, for example, there were three fires reported on 21 June and 22 fires reported between 6 and 10 July. 


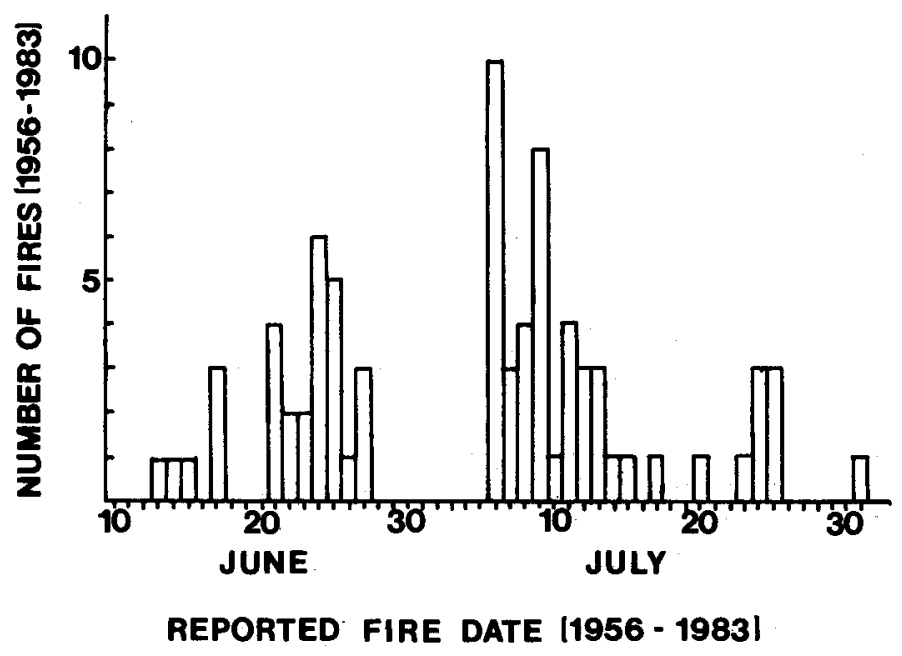

FIG. 4. Frequencies of dates of 77 fires, reported by BLM, that occurred in the Noatak River watershed between 1956 and 1983. (No information is available for two fires.)

Nevertheless, even in these three years there were no fires during the period 28 June -5 July.

\section{DISCUSSION AND CONCLUSIONS}

The techniques we have used, accurate mapping of fires, and the analysis of other related information from both fire records and LANDSAT imagery have demonstrated several important aspects of the tundra fire regime in the Noatak River watershed. We have extended the regional approach to fire history, advocated for Alaska by Gabriel and Tande (1983), one step further to a watershed unit and its subdivisions to examine locational and temporal patterns of burning in this $33670 \mathrm{~km}^{2}$ area of predominantly arctic tundra.

The preliminary finding that in most years there is only a brief one- to three-day period when conditions for tundra fire ignitions are met suggests that the combination of thunderstorm activity following drying periods of sufficient length to produce burnable fuels occurs only rarely. Weather patterns observed during our field studies in the Noatak suggest that conditions suitable for burning developed only when winds were from the east or northeast (i.e., from interior Alaska). These winds were accompanied by periods of clear skies, low humidity, and generally warm weather. The periodicity of fire occurrence appears to be related to weather patterns and to fuel flammability as it is affected by the phenological behavior of plants. Reburning of tundra can occur within 6-10 years following fires, suggesting that fuel buildup can be rapid.

These observations also suggest that tundra fire effects in terms of severity of burning and impact on seasonal plant growth may be significantly influenced by system phenology. Some evidence for this can be seen on black and white LANDSAT imagery. Tundra fires in the Noatak watershed that occur during July are visible on LANDSAT for three years following their occurrence, whereas two 23 June 1974 fires are not visible on July 1977 LANDSAT imagery. This contrast in length of visibility on LANDSAT imagery suggests that regrowth of vegetation following June fires is more rapid than after July fires, or alternatively, that there is reduced severity of early fires that occur when the depth of thaw is shallow and soil moisture levels are high, compared to later fires that occur when the depth of thaw is deeper and soil moisture levels are lower.

There is a general trend of more patchy burning and smaller mean fire size with increasing elevation and distance from the river and distance upriver in the watershed. This trend is probably associated with more mountainous and dissected topography producing an uneven distribution of fuels. There is some evidence that lightning strikes and ignitions may be more frequent in these higher-elevation, upriver regions and that fires resulting from these ignitions are often quickly extinguished by rain.

Our results have shown that fire regimes vary within the Noatak watershed in response to differences in terrain, elevation, and possible weather patterns.

Surveillance and detection of fires of small size and in remote locations within the watershed have undoubtedly increased in recent years and influence our fire regime statistics: only 4 of the 79 fires recorded for the 28 -year study period are reported for the period 1956-67. Therefore, calculations of fire rotation times for the watershed and its subdivisions below $450 \mathrm{~m}$ vary depending on whether statistics from 1968 to 1983 (16 years) or from 1956 to 1983 (28 years) are used. Fire rotation time for the Mission Lowlands below $450 \mathrm{~m}$ is only 150 years for the 1968-83 statistics, as compared with 252 years for the 1956-83 period. Rotation time for the Second Highlands region is reduced from 442 years using the 1956-83 records to 250 years using the 1968-83 data. The Aniuk Lowlands region has the longest fire rotation times: 350 years for the 16-year period and 600 years for the 28 -year period.

\section{Comparisons with Other Tundra Areas}

The frequency and extent of wildfire in the Noatak watershed appear to be much greater than in other tundra regions of the Brooks Range and North Slope of arctic Alaska. Barney and Comiskey (1973), for example, describe only 5 fires that burned a total area of $16.6 \mathrm{~km}^{2}$ on the North Slope between 1969 and 1971. In the Noatak during this same period, we report 11 fires that burned $226 \mathrm{~km}^{2}$. Similarly, thunderstorm activity in June 1971, as viewed from an aerial survey plane over the central Brooks Range, was seen to be localized over the western Brooks Range or Noatak region (Barney and Comiskey, 1973). During the summer of 1977, a heavy fire year in northwestern Alaska, we found that $640 \mathrm{~km}^{2}$ burned in the Noatak watershed, whereas the only reported fires on the North Slope in 1977 were a $48 \mathrm{~km}^{2}$ fire on the Kokolik River (Hall et al., 1978) and at least two other small fires of $0.1 \mathrm{~km}^{2}$ and $12 \mathrm{~km}^{2}$ elsewhere on the North Slope (National Petroleum Reserve in Alaska (NPR-A) Task Force, 1978).

Although tundra fire appears to be more extensive in the Noatak region than to the east and north in arctic Alaska, fire frequency and area burned are greater in the Seward Peninsula than in the Noatak. During the summer of 1971, over 1600 $\mathrm{km}^{2}$ of tundra burned in the Seward Peninsula (cf. Wein, 
1976), whereas only $330 \mathrm{~km}^{2}$ burned in the Noatak. During 1977 more than $3000 \mathrm{~km}^{2}$ burned in the Seward Peninsula (Viereck and Schandelmeier, 1980), but only $640 \mathrm{~km}^{2}$ burned in the Noatak watershed. Although the Seward Peninsula is an area almost twice as large as the Noatak watershed, the fire rotation time in the Seward is considerably shorter than that for the Noatak. These preliminary comparisons of tundra fire frequency and extent across arctic Alaska suggest a declining gradient of importance of fire in tundra ecosystems from the Seward Peninsula to the north and east.

\section{ACKNOWLEDGEMENTS}

This research was supported by a grant from the U.S. Man and the Biosphere (MAB) program. Dr. Gary Ahlstrand (National Park Service, Anchorage, $A K$ ) and Mack Shaver (National Park Service, Kotzebue, AK) obtained BLM fire records for us. Katie Martz (Geophysical Institute, University of Alaska) assisted us in locating imagery.

\section{REFERENCES}

BARNEY, R.J., and COMISKEY, A.L. 1973. Wildfires and thunderstorms on Alaska's north slopes. USDA Forest Service Pacific Northwest Forest and Range Experiment Station, Portland, OR. Research Note PNW-311. $8 \mathrm{p}$.
GABRIEL, H.W., and TANDE, G.F. 1983. A regional approach to fire history in Alaska. USDI Bureau of Land Management, Alaska Technical Report 9.34 p.

HALL, D.K., BROWN, J., and JOHNSON, L. 1978. The 1977 tundra fire in the Kokolik River area of Alaska. Arctic 31:54-58.

HEINSELMAN, M.L. 1973. Fire in the virgin forests of the boundary waters canoe area, Minnesota. Quaternary Research 3:329-382.

1978. Fire intensity and frequency as factors in the distribution and structure of northern ecosystems. In: Mooney, H., et al., eds. Proceedings, Fire Regimes and Ecosystem Properties. USDA Forest Service General Technical Report WO-26. 593 p.

NATIONAL PETROLEUM RESERVE IN ALASKA TASK FORCE. 1978. Ecological Profile. USDI National Petroleum Reserve Alaska. Land Use Study Report 4. $118 \mathrm{p}$.

QUIRK, W.A., and SYKES, T.J. 1971. White spruce stringers in a fire-patterned landscape in interior Alaska. In: Slaughter, C.W., Barney, R.J., and Hansen, G.M., eds. Proceedings, Fire in the Northern Environment - A Symposium. U.S. Forest Service, Portland, Oregon. 179-197.

SMITH, P.S. 1913. The Noatak-Kobuk Region, Alaska. U.S. Geological Survey Bulletin 536. $160 \mathrm{p}$.

TANDE, G.F. 1979. Fire history and vegetation patterns of coniferous forests in Jasper National Park, Alberta. Canadian Journal of Botany 57:19121931.

VIERECK, L.A., and SCHANDELMEIER, L.A. 1980. Effects of fire in Alaska and adjacent Canada - a literature review. USDI Bureau of Land Management, Alaska Technical Report 6. 124 p.

WARHAFTIG, C. 1965. Physiographic divisions of Alaska. USDI Geological Survey Professional Paper 482. 52 p.

WEIN, R.W. 1976. Frequency and characteristics of arctic tundra fires. Arctic 29:213-222. 